Journal of Applied Sports Seienee

June 2015, Volume 5, No. 2

\title{
The Effeet of the Program of Using the Technology Education to Learning Some Basic Skills in Baskethall.
}

\section{Tarek M. Abdel Rauef}

Games Department of Physical Education College, Sadat City University, Egypt.

\begin{abstract}
The study aims to design an educational program by using Whats App program on mobile phones in order to learn some basic skills in basketball and to recognize the effect of the program on students learning basketball skills. The researcher used the experimental method by using two groups one of them is the experimental group (19students) and the other is the control group (19 students). They were chosen deliberately from basketball students of Physical Education department, the statistical results indicated that The experimental program using the mobile phone in learning affects positively the ability development to learn some basic skills in basketball in the experimental group and using learning through mobile phone in the athletic education had a greater effect in learning basketball skills studied in the research than the classic style.
\end{abstract}

Key word: mobile phones in learning, basic skills, basketball..

\section{Introduction:}

$\mathrm{T}$ The student is the essence of educational process; the researcher noticed the decrease of the expected skilled performance of the students of Physical Education department in basketball course (1). The researcher attributes this decrease to the unsuitability and shortage of the followed teaching methods and to the short time of the lecture which is 100 minutes per week. And regarding that basketball includes a big group of skills for its diverse, from here lies the need to make use of the positive role of mobile phones in the educational process; as they contribute in improving learning, increasing its effectiveness, saving time of learning and helping the student to recognize the best ways of skill performance. As the mobile phone has invaded most of scholar materials, so we must make use of this technology quickly through using the advanced techniques in teaching.

\section{Study aims:}

1. to design an educational program by using Whats App on mobile phones in learning some basic skills in basketball.

2. To recognize the effect of the program on students' learning of basketball skills.

\section{Research procedures:}

\section{First: Research Method:}

The researcher used the experimental method by using two groups (experimental group and control group) as it suits the nature of the research.

\section{Second: Research Sample:}

The research sample was chosen deliberately and randomly from students of Physical Education department of the scholar year 2012 - 2013, the second semester registered in basketball course (1). The researcher chose two groups one experimental and the other the control group, their number was 39 students; he excluded one student from the control group for his previous practice of basketball. Two other groups were excluded for the existence of many students who practiced basketball in different percentage which may affect the results of the research.

\section{The equivalence of sample personnel:}

The researcher found the coherence of research sample as a whole, its number was (38) student to make sure that it is under the equivalent curve in the following variables:

- Growth rates (height - weight).

- Physical Education components of basketball(agility ability - endurance - speed). 
Table (1)

The statistical description of Physical Education department students registered in basketball course (1) in the variables of (growth - physical variables)

\begin{tabular}{|c|c|c|c|c|c|}
\hline variables & $\begin{array}{c}\text { Measureme } \\
\text { nt unit }\end{array}$ & means & medium & $\begin{array}{c}\text { Standard } \\
\text { deviation }\end{array}$ & $\begin{array}{c}\text { Coefficient of } \\
\text { torsion }\end{array}$ \\
\hline height & $\mathrm{cm}$ & 167.45 & 167 & 5.14 & 0.01 \\
\hline weight & $\mathrm{kgm}$ & 65.42 & 65 & 5 & 0.12 \\
\hline Spiral running test & second & 15.73 & 15.75 & 0.74 & 1.05 \\
\hline Running test 50m & second & 7.41 & 7.1 & 0.82 & 0.26 \\
\hline Long jump test & $\mathrm{cm}$ & 213.26 & 210 & 15.54 & 0.36 \\
\hline Running 550m & $\mathrm{m}$ & 125.84 & 125.5 & 6.18 & 0.42 \\
\hline
\end{tabular}

Table (1) shows that coefficients of torsion of research sample are between $(+3,-3)$ in the variables of (growth - physical education) which indicates the coherence of the sample.

Then the researcher calculated the equivalence between the research two groups of the variables that may affect the educational program which are (growth - intelligence - physical education - basic skills) as table (2) shows

Table (2)

The significance of differences between the experimental and control groups in the before measurements of research sample

\begin{tabular}{|c|c|c|c|c|c|c|c|}
\hline \multirow{2}{*}{ variables } & \multirow{2}{*}{ Measurement unit } & \multicolumn{2}{|c|}{ Experimental group } & \multicolumn{2}{|c|}{ Control group } & \multirow{2}{*}{$\begin{array}{c}\text { Means } \\
\text { difference }\end{array}$} & \multirow{2}{*}{$\begin{array}{l}\text { calculated } \\
\text { "T" value }\end{array}$} \\
\hline & & average & s.d & average & s.d & & \\
\hline Height & $\mathrm{cm}$ & 168.68 & 4.77 & 166.21 & 5.32 & 2.47 & 0.07 \\
\hline Weight & kgm & 66.74 & 4.36 & 64.11 & 5.36 & 2.63 & 0.05 \\
\hline Spiral running test & second & 15.77 & 0.82 & 15.7 & 0.66 & 0.07 & 0.37 \\
\hline Running test $50 \mathrm{~m}$ & second & 7.46 & 0.79 & 7.37 & 0.86 & 0.09 & 0.37 \\
\hline Long jump test & $\mathrm{cm}$ & 212.79 & 17.89 & 213.74 & 13.25 & -0.95 & 0.427 \\
\hline Running 550m & $\mathrm{m}$ & 125.47 & 6.35 & 126.21 & 6.16 & -0.74 & 0.36 \\
\hline
\end{tabular}

The previous table shows the lack of statistically significant differences between the experimental and control groups in all the variables of the research which shows the sample equivalence.

\section{Third: Tools of Data Collection:}

The research included the following means of data collection:

- Tools of measuring growth rates (height weight).

- $\quad$ Physical tests enclosed (1)

The physical tests (the spiral running test which measures agility - the running for $50 \mathrm{~m}$ test which measures the speed - the running for $550 \mathrm{~m}$ which measures the physical endurance - the long jump test which measures muscles' ability).

Fourth: the suggested educational program:

The design of Whats App program:
The design of an educational program of basketball skills by using Whats App program is considered one of research aims, so the researcher reviewed the Arabic and foreign researches and studies which addressed this topic. The purpose of the suggested program is to learn some basketball skills (ball catch - Dribbling -Some types of passing - Some types of Shooting).

The researcher has been select these skills because its included in the course of basketball (1) wish the students are going to study in that semester .

\section{The aim of the suggested program:}

- The general aims of the suggested educational program were formed by using mobile phones for learning basketball to students of basketball course (1) from the faculty of education - King Feisal University, so as to reach a behavioral procedural image which can be noticed and measured through: 
The first general aim: after the student finishes the educational program, he becomes able to:

1- The student excels the performance of basic skills of basketball, which are:-

* Ball catch

* Dribbling

* passing (chest - Bounce - from up the head - shoulder with one hand)

* Shooting (Shooting down the loop - free throw - Layup-shot - by jump)

1- The student recognizes the educational steps of basketball basic skills.

\section{The bases of program making:}

The researcher took into consideration the following bases when making the educational program to learn some basketball skills:

1. To take into consideration the individual differences between students.

2. The educational program must be simple and diverse.

3. To be advancing from the easy to the difficult.

4. That the program content be suitable for the desired aims.

Seventh: the researcher reviewed the scientific references in order to determine the general aims of the educational program.

\section{Fifth: pilot study:}

The researcher performed a pilot study on a similar sample and from outside the original sample its number was (10) students on $9 / 2 / 2013$ then he re-performed the experiment on $16 / 2 / 2013$ to make sure of their ability to understand working with mobile phones by using Whats App program and to recognize the problems facing the process of program executing by students. The pilot study found that there are no difficulties facing program execution.

\section{Sixth: the basic experiment:}

The basic experiment of research began on Saturday $23 / 2 / 2013$ to Sunday 28/4/2013, the program execution took 8 weeks -among which one week of mid- term vacation according to the scholar calendar in Saudi Arabia, for 2 hours per week. The researcher used the experimental method; he chose two groups one experimental and the other control group. Students' number was 40, and 1 student was excluded for his previous practice of basketball. He also chose a pilot group of 11 students, and excluded 1 student from the pilot group, he also excluded two other groups because a big percentage of them practiced basketball previously in different percentages which may affect the results of the research. The researcher processed the results statistically by using the statistical program SPSS. After applying the suggested program which included sending some training of learning and developing special skills of basketball 2 days before the lecture date, the after measuring of the two research groups was performed on $4-5 / 5 / 2013$.

\section{Seventh: the statistical treatments:}

The researcher treated the study statistically by using the statistical program SPSS.

1- The percentage, the arithmetic means the standard deviation.

2- The differences' significance.

\section{The results:}

First: the display of results: in the light of research aims and its procedures, the researcher displays the research results as follows:

Table (3)

The test of differences' significance between the means of before \& after measurements of the control group in the studied variables

\begin{tabular}{|c|c|c|c|c|c|c|c|}
\hline \multirow{2}{*}{ variables } & \multirow{2}{*}{$\begin{array}{c}\text { Measurement } \\
\text { unit }\end{array}$} & \multicolumn{2}{|c|}{ Before measurement } & \multicolumn{2}{|c|}{ After measurement } & \multirow{2}{*}{$\begin{array}{c}\text { Means } \\
\text { difference }\end{array}$} & \multirow{2}{*}{$\begin{array}{l}\text { calculated } \\
\text { "T" value }\end{array}$} \\
\hline & & average & s.d & average & s.d & & \\
\hline Chest pass & points & 15.36 & 1.78 & 21.02 & 1.59 & 5.66 & $* * 9.76$ \\
\hline Bounce Pass & Points & 12.61 & 2.93 & 16.33 & 2 & 3.72 & $* * 4.01$ \\
\hline Dribbling & Points & 7.17 & 0.63 & 6.25 & 0.28 & 0.92 & $* * 5.87$ \\
\hline Shooting down the loop & Points & 8.58 & 2 & 12.94 & 1.59 & 4.36 & $* * 6.94$ \\
\hline Lay-up-shot & Points & 1.78 & 0.73 & 10.39 & 1.09 & 8.61 & $* * 24.35$ \\
\hline Free throw & points & 3.83 & 1.65 & 10.28 & 1.07 & 6.44 & $* * 13.25$ \\
\hline
\end{tabular}

* Significant at the morale level $.05 \quad * *$ significant at the morale level.01 
Table (3) shows that There are significant differences at the level of significance (0.01) in compiling the tribal and posttest for the benefit of the telemetric control group in all performance variables skill under discussion.

Table (4)

The test of differences' significance between the means of before $\&$ after measurements of the experimental group in the studied variables

\begin{tabular}{|c|c|c|c|c|c|c|c|}
\hline \multirow{2}{*}{ variables } & \multirow{2}{*}{$\begin{array}{l}\text { Measurement } \\
\text { unit }\end{array}$} & \multicolumn{2}{|c|}{ Before measurement } & \multicolumn{2}{|c|}{ After measurement } & \multirow{2}{*}{$\begin{array}{c}\text { Means } \\
\text { difference }\end{array}$} & \multirow{2}{*}{$\begin{array}{c}\text { calculated "T" } \\
\text { value }\end{array}$} \\
\hline & & average & s.d & average & s.d & & \\
\hline Chest pass & points & 15.61 & 1.69 & 23.78 & 1.7 & 8.17 & $* * 15.36$ \\
\hline Bounce Pass & Points & 12.17 & 2.26 & 18.39 & 2.06 & 6.22 & $* * 8.37$ \\
\hline Dribbling & Points & 7.07 & 0.49 & 5.69 & 0.52 & 1.38 & $* * 8.18$ \\
\hline Shooting down the loop & Points & 8.81 & 1.72 & 14.33 & 1.88 & 5.53 & $* * 9.01$ \\
\hline Lay-up-shot & Points & 2 & 1.03 & 15.06 & 1 & 13.06 & $* * 45.73$ \\
\hline Free throw & points & 3.5 & 1.29 & 12.83 & 1.5 & 9.33 & $* * 26.49$ \\
\hline
\end{tabular}

* Significant at morale level .05

** significant at morale level .01

Table (4) shows that There are significant differences at the level of significance (0.01) in compiling the tribal and post test for the benefit of the telemetric experimental group in all performance variables skill under discussion.

Table (5)

The test of differences' significance between the means of before $\&$ after measurements of the experimental group and the control group in the studied variables

\begin{tabular}{|c|c|c|c|c|c|c|c|}
\hline \multirow{2}{*}{ variables } & \multirow{2}{*}{$\begin{array}{c}\text { Measurement } \\
\text { unit }\end{array}$} & \multicolumn{2}{|c|}{ Before measurement } & \multicolumn{2}{|c|}{ After measurement } & \multirow{2}{*}{$\begin{array}{c}\text { Means } \\
\text { difference }\end{array}$} & \multirow{2}{*}{$\begin{array}{c}\text { calculated "T" } \\
\text { value }\end{array}$} \\
\hline & & average & s.d & average & s.d & & \\
\hline Chest pass & points & 21.02 & 1.59 & 23.78 & 1.7 & 2.76 & $* * 4.85$ \\
\hline Bounce Pass & Points & 16.33 & 2 & 18.39 & 2.06 & 2.06 & $* * 3.03$ \\
\hline Dribbling & Points & 6.25 & 0.28 & 5.69 & 0.52 & 0.57 & $* * 4.51$ \\
\hline Shooting down the loop & Points & 12.94 & 1.59 & 14.33 & 1.88 & 1.39 & $* * 3.43$ \\
\hline Lay-up-shot & Points & 10.39 & 1.09 & 15.06 & 1 & 4.67 & $* * 15.43$ \\
\hline Free throw & points & 10.28 & 1.07 & 12.83 & 1.5 & 2.56 & $* * 5.33$ \\
\hline
\end{tabular}

* Significant at morale level .05

** significant at morale level .01

Table (5) shows that There are significant differences at the level of significance $(0.01)$ in compiling the post to both groups for the benefit of telemetric experimental group in all performance variables skill under discussion.

\section{The discussion:}

First: the explanation of the differences' results between the means of before and after measurements of both experimental and control groups:

Tables $(3,4)$ show that there are statistically significant differences between the means of before measurements and the means of the after measurements in the skills tests studied in the research. This indicates that both the classic and the suggested programs achieved a progress. The researcher attributes this to the fact that the trainings are performed regularly either in the classic program or in the suggested program. The researcher attributes the performance improvement of basketball skills of control group individuals to the existence of teaching board member who presents a clear idea of the right way of performance which makes it more effective and who presents the correct feedback to the students from time to time during the lecture and who comments on the common mistakes and the way of correcting them. This result agrees with what Hanfy Mukhtar 1989 [1] referred to that the degree of players' performance depends on the teacher's ability of good verbal explanation of the performance concerning the right postures of all body parts during movement skill performance. Also the trainings are performed according to organized programs and under the supervision of a qualified teacher. This agrees with what Tarek Abdel Ra'of 1993 [2], Adel Ramadan 1997 [3] and Shahira abdel Wahab 1998 [4] reached, as all of them agreed in their studies that the 
student's regularity in a rationed educational and training program under the supervision of a scientifically qualified person will result in a positive effect.

This shows that, and concluding from the previously displayed results, the researcher sees that the first and second hypotheses of the research are achieved which are:

1. The educational program by using the Whats App program on the mobile phone has a positive effect in learning some basic skills of basketball.

2. There are statistically significant differences between the before and after measurements, in favor of the after measurement of both the experimental and control groups.

Second: the explanation of differences' results between the means of after measurements of both experimental and control groups:

Table (5) shows that there are statistically significant differences in the two after measurements of both the experimental and the control groups in the skills' tests studied in the research in favor of the experimental group. The researcher attributes this result to that the use of Whats App program in teaching deepens the students' understanding of movement skills. It also contributes in refining the skill as a whole. Whats App program also displays and explains the movement of body parts during skills performance and focuses on the important parts of performance in each skill, which positively affects students' learning of different skills. This result agrees with the study of (Yaakub \& Alzaza, 2011)[5] which found that students who use mobile phones in learning have confirmed the benefit of this kind of learning regarding the facility of using, the ability to learn anytime and at any place, and the high educational efficiency which the mobile phone presents. It also agreed with the study of Al khamdy (2013) [6] that the mobile learning allows the student to be free during the process of learning as it enables them to learn anytime and at any place without being committed to the university campus. This also agreed with the study of Alharthy (1428) [7] that there is a positive effect on the students in absorbing the vocabulary of the course. This also agreed with the study of Tshing (2007) [8] in which one of the most important results was the existence of an effect on the level of knowledge gain as a result of using this method of mobile learning through text messages. this also agreed with the study of Kim, Mims, \& Holmes (2006) cited from Al khamedy (2013) [6] that learning by using mobile phones resulted in achieving many benefits to all; the lecturers and the students beside the existence of some obstacles and negative effects. Finally, the researcher agrees with Gebril Al Arishy and Maha Al Atas [9] that learning through mobile phones has many educational benefits which make us get interested in this kind of learning and also recommend the necessity of performing many researches about this type, how to use it and benefit from it in the learning process in its different phases.

\section{This result confirms the third hypothesis which states that:}

There are statistically significant differences in the after measurement (between the experimental and the control groups)

\section{Conclusions:}

In the light of research aims and hypotheses, and in the limit of research sample and what the statistical results indicated, the researcher reached the following conclusions:

1. The experimental program using the mobile phone in learning positively affects the ability development to learn some basic skills in basketball in the experimental group.

2. The classic program positively affects the ability development to learn some basic skills in basketball in the control group.

3. The use of learning through the mobile phone in the athletic education had a greater effect in learning basketball skills studied in the research than the classic style.

\section{Recommendations:}

In the light of the research results and conclusions, the researcher recommends the following:

1. To use the training program using Whats App program in learning and developing basketball skills.

2. To make use of Whats App program in teaching players how to perform attack and defensive movements inside the playground.

3. To teach players the attack and defensive plans through Whats App program which helps in repeating the way of performance as shown in the potential plans of attack and defense.

4. To make use of Whats App program in teaching players other skills in different sports.

5. To make use of Whats App program in different age stages.

\section{References:}


1. Hnanfy M. Mokhtar, 1989, the physical preparation in football, Zahran House.

2. Tarek M. Abdel Ra'of, 1993: "the effect of training program with weights on some physical fitness elements in basketball", Master thesis, Faculty of Physical Education for girls in Cairo, Helwan University, 1993.

3. Adel Ramadan, "the effect of developing the aerobic and anaerobic work on some physical characteristics and some basic skills in basketball for youth from 14 - 16 years". An unpublished Master thesis, faculty of physical education, Suez Canal University, Portsaid, 1997.

4. Shahira Abdel Wahab, "the effect of periodical training on some physical and psychological variables and on the performance level of rhythm trainings", 3rd Vol. of the scientific conference researches, Helwan University, 1998.

5. http://www.albayan.ae/science-today/educationcom/2012-11-11-1.1764328

6. Fayek Saied Al Khamedy, the use of mobile phone learning in developing practical skills and absorbance of students of Albaha University. .Cybrarians Journal. Issue 31 (June 2013).

7. Mohamed Attia Alharthy, (2008), the mobile phone learning: the experiement of using short text messages of mobile phones in university learning. The 7th international conference of electronic learning (towards the society of knowledge), Egypt: the association of technological and human development.

8. Jung-Tsung Yang،et al. ( 2007). Mobile learning practice: a preliminary study on a mobile system of customs cargo inspection.Proceedings of the 6th Conference on WSEAS International Conference on Applied Computer Science Volume 6.World Scientific and Engineering Academy and Society،April.

9. Gebril Bin Hassan Alareshy and Maha Abdel Bary Alattas (the effectiveness of using mobile phones in developing the technical conceptions of sample of high studies' students of King Saud University) 2012, issues 26, December 2012, the magazine of Education Faculty, Aswan University. 
